\title{
COMPARISON OF METHANE OXIDATION POTENTIAL BETWEEN COMPOST AND BLACK SOIL AT JERAM LANDFILL
}

\author{
Boon Tien L.* and Agamuthu P.
}

Institute of Biological Sciences, University of Malaya 50603 Kuala Lumpur, Malaysia.

*boon_tien85@hotmail.com (Corresponding author)

Received on 6th July 2011, accepted in revised form 11th July 2011.

\begin{abstract}
Landfills are significant sources of atmospheric methane $\left(\mathrm{CH}_{4}\right)$ that contributes to greenhouse gas effect, and therefore there is a need to reduce the $\mathrm{CH}_{4}$ emissions from landfills. Small scale landfills in Malaysia and other developing countries generally do not generate enough $\mathrm{CH}_{4}$ for energy harvest. $\mathrm{CH}_{4}$ emission can be reduced by means of microbial oxidation enhanced by biologically engineered landfill covers. This is a promising cost-effective technology to enhance biological oxidation of $\mathrm{CH}_{4}$ in small scale landfills. The selection of suitable materials represents one of the key issues in constructing biotic $\mathrm{CH}_{4}$ oxidation systems. Composts and black soil have been proven to support $\mathrm{CH}_{4}$ oxidation and they represent a low cost alternative to other sandy or humic-rich soil substrate. This study was carried out to investigate the $\mathrm{CH}_{4}$ oxidizing capacity of compost and black soil under field conditions. Experiments with different flow rates of landfill gas have shown that compost has a higher oxidation capacity compared to black soil. At $100 \mathrm{~cm}$ of cover height and flow rate of $300 \mathrm{ml}$ per minute, black soil

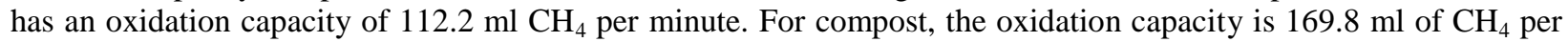
minute. From this study we concluded that compost has greater potential than black soil as landfill cover material due to the better $\mathrm{CH}_{4}$ oxidation capacity.
\end{abstract}

(Key words: $\mathrm{CH}_{4}$ oxidation, compost, black soil, Biocover)

\section{INTRODUCTION}

Wastes are discards that are no longer useful or required after the completion of a certain process. Currently, on average, Malaysians produces about $1.3 \mathrm{~kg} /$ capita of MSW. However, in urban areas such as Kuala Lumpur, Petaling Jaya and Georgetown, the rate can be up to $2.0 \mathrm{~kg} /$ capita [1]. Due to the high per capita generation, daily generation of MSW in Malaysia totaled to more than 31,000 tonnes where $95 \%$ of it will be sent to landfill. The practice is absolutely unfavorable in most of the developed nation as it will result with total loss of resources to landfilling process. Landfilling is the most favored practice in Malaysia since recycling or material recovery only covers $5 \%$ of the total waste generated [2].

Most landfills in Malaysia are small scale operations with a variety of technology being used. However, most of the sites are poorly managed. As of January 2011, there are a total of 296 landfills in Malaysia, with 166 being operational and 130 more being closed. However, of the total of 166 active landfills, there are only 8 of which are sanitary landfills [3].

Landfills containing organic wastes produce landfill gas (LFG) consisting primarily of $\mathrm{CH}_{4}$ and carbon dioxide. Landfills are significant sources of atmospheric $\mathrm{CH}_{4}$ that contribute to climate change [4]. $\mathrm{CH}_{4}$ emissions from landfill are ranked third among the anthropogenic $\mathrm{CH}_{4}$ sources and ranged between $19-40 \mathrm{Tg} / \mathrm{yr}$. $\mathrm{CH}_{4}$ is recognized as a potent greenhouse gas with the global warming potential of approximately 25 times than that of carbon dioxide [5]. The annual global $\mathrm{CH}_{4}$ emissions from landfills are estimated to be in the range of 500-800 MT CO2eq, representing the highest source of greenhouse gases within the waste sector [4].

Biocover is a layer of biologically engineered soil or compost, able to oxidize $\mathrm{CH}_{4}$ generated by landfill. In 
Malaysia, the typical landfill gas components are $\mathrm{CH}_{4}$ (55-60\%) and carbon dioxide (40-45\%) with the rest being carbon monoxide, hydrogen sulfide and ammonia. Many landfills in Malaysia and other developing countries are not equipped with LFG extraction facilities and have been covered with low permeable clay soils to reduce infiltration of water to the waste layers. Besides, the quantity of produced gas is often too low for gas utilization systems to be economically feasible and therefore, Biocover represents a cost-efficient solution. Usage of biologically engineered cover materials might be needed at older landfills with a relatively low gas production. The selection of suitable materials represents one of the key issues in constructing biotic $\mathrm{CH}_{4}$ oxidation systems. In general, well textured, porous substrates should be employed since they provide sufficient porosity for gas exchange, facilitating the penetration of oxygen from the atmosphere and $\mathrm{CH}_{4}$ supply from waste, with both being crucial to microbial $\mathrm{CH}_{4}$ oxidation processes. Besides, the microbial oxidation process is also influenced by other factors such as temperature, moisture content and the prevailing physical and chemical soil conditions [6]. Numerous composts and soils have been investigated by our centre in various studies aimed at assessing $\mathrm{CH}_{4}$ oxidation. The abovementioned materials were tested under similar laboratory conditions in Wheaton bottle set-ups. The data set has been compiled focusing on routine chemical, physical and maturation parameters. Finally, it has been established that compost from grass clippings and cow manure provides the most optimum $\mathrm{CH}_{4}$ oxidation under laboratory conditions

The aim of this study is to identify the materials suitable for Biocover and also the $\mathrm{CH}_{4}$ oxidation capacity of compost and black soil under field conditions.

\section{MATERIALS AND METHOD}

\section{Experimental materials}

Compost was obtained by composting a mixture of $75 \%$ grass clippings and 25\% cow manure. The materials were uniformly mixed to ensure even distribution of microbes for optimum composting to occur. Heap method was employed in the process and composting was carried out under a well aerated shade. Water was added to the compost mixture to maintain the moisture level at $60 \%$ for proper decomposition of the raw materials. Proper aeration and aerobic condition was maintained by manual turning of composting mixture with daily mixing for the first 8 days and then mixing on alternate days. Temperature of the composting mixture was measured daily using the electronic thermometer (model Oregon scientific SA880SSX). The moisture content was determined gravimetrically by oven drying compost at $104^{\circ} \mathrm{C}$ for 24 hours and expressed as the mass ratio of water to drying compost, following the ASTM (2004) procedure. The pH of the compost was measured using the $\mathrm{pH}$ meter model HANNA HI 8424. The organic matters were obtained according to ASTM 830-97 standard method. The total Carbon was obtained according to ASTM 77787 (96) method and total Nitrogen was obtained according to the ASTM E778-87 respectively. Black soil was obtained from a local nursery.

\section{Site characterization}

Field study was carried out at Jeram Sanitary Landfill. The Jeram Sanitary Landfill is an active landfill located at Lot No. 1595, 2598, 2959 in Jeram Town, Kuala Selangor district with an approximate area of 160 acres. Former land-use was agriculture. The landfill is currently awarded a 25 year privatization-cum-concession for the construction, operation and maintenance of the area. A total of approximately 2100 tonnes of municipal solid waste is disposed of at the landfill daily. The dominating waste types are domestic waste, bulky waste and garden waste. The landfill caters for seven major municipalities in Klang Valley namely Kuala Selangor, Subang Jaya, Klang, Petaling Jaya, Shah Alam, Ampang Jaya and Selayang. JSL started operation on $1^{\text {st }}$ January 2007 with an expected lifespan of 16 years dependant on the amount of wastes received.

\section{Column reactor experiments}

Hot spots for landfill gas emissions were identified onsite with portable gas analyzer Binder CombiMass GA-M Type GFM 415-1 at different sections of the landfill. Surface LFG emissions readings and LFG emissions from sampling ports present at landfill at various locations were evaluated quantitatively and qualitatively. These field measurements were generally planned so that measurements were carried out under stable weather conditions, where the measured emissions are believed to be representative for the whole landfill emission rate at the particular time. The gas sampling port GV1 at Jeram Landfill was selected as experimental site. 
One-meter high columns were specially fabricated using $10 \mathrm{~mm}$ thick PVC pipes with an internal diameter of $0.14 \mathrm{~m}$ (Figure 1). Sampling ports were embedded in the columns at an interval of $0.1 \mathrm{~m}$ to enable gas sampling at different heights. Biocover materials were placed in the columns with the top of the column being sealed with $5 \mathrm{~mm}$ thick Plexiglas.

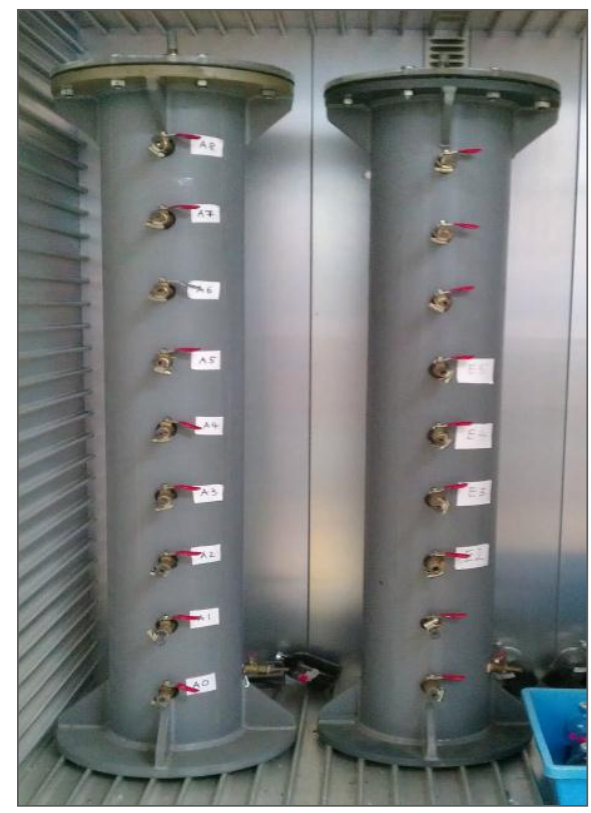

Figure 1: BioCover column
LFG were introduced into the cover material through the bottom inlet valves. Gas composition and pressure were monitored at selected profiles. At the bottom of the column, controlled flow of LFG was

introduced using Dwyer Rate-Master Flow meter through an inlet. Exhaust gas from each sampling port was analyzed using the portable gas analyzer Binder CombiMass GA-M Type GFM 415-1 for $\mathrm{CH}_{4}$, carbon dioxide and oxygen. Column reactor experiments were conducted in triplicates using compost and black soil with flow rates of 100 $\mathrm{ml} / \mathrm{min}, 200 \mathrm{ml} / \mathrm{min}$ and $300 \mathrm{ml} / \mathrm{min}$. Readings were taken at the temperature of $35^{\circ} \mathrm{C}$ during the day as it is acknowledged that it is the optimum temperature for $\mathrm{CH}_{4}$ oxidation to occur.

\section{RESULTS AND DISCUSSION}

Landfill gas (LFG) is produced by microbial anaerobic degradation of the organic fraction in waste disposed in landfills. The biodegradable organic materials in waste mostly include paper, animal and vegetable matter, and garden waste. The main components in LFG are $\mathrm{CH}_{4}$ (55-60\%), and carbon dioxide $(40-45 \%)$. Table 1 shows the average percentage of surface $\mathrm{CH}_{4}$ emissions of JSL for the past one year.

Table 1. Average percentage of $\mathrm{CH}_{4}$ emissions at Jeram Sanitary Landfill

\begin{tabular}{|c|c|c|c|c|c|c|c|c|c|c|c|c|}
\hline Month & July & Aug & Sept & Oct & Nov & Dec & Jan & Feb & Mar & Apr & May & June \\
\hline $\begin{array}{c}\mathbf{C H}_{\mathbf{4}} \\
(\boldsymbol{\%})\end{array}$ & 48.43 & 59.83 & 56.42 & 39.44 & 48.78 & 49.52 & 53.70 & 45.65 & 57.36 & 53.94 & 53.73 & 55.48 \\
\hline
\end{tabular}

Figures $2 \mathbf{a}, \mathbf{b}$, and $\mathbf{c}$ shows the reduction of $\mathrm{CH}_{4}$ in exhaust gas with the increased flow rate of LFG input respectively for black soil. The height needed to fully oxidize the $\mathrm{CH}_{4}$ from LFG increases with the respective increase in the flow rate. However for the flow rate of $300 \mathrm{ml} / \mathrm{min}, 100 \mathrm{~cm}$ of black soil is unable to fully oxidize the input of $300 \mathrm{ml}$ per minute of LFG. The maximum oxidation capacity of $100 \mathrm{~cm}$ of black soil is $112.2 \mathrm{ml}$ of $\mathrm{CH}_{4}$ per minute. Figures $\mathbf{3 a}, \mathbf{b}$ and $\mathbf{c}$ show the reduction of $\mathrm{CH}_{4}$ in exhaust gas with the increased flow rate of LFG input respectively for compost. The height of $100 \mathrm{~cm}$ for compost can fully oxidize a maximum of $300 \mathrm{ml}$ per minute of LFG. Therefore the maximum oxidation capacity of compost at $100 \mathrm{~cm}$ is $169.8 \mathrm{ml}$ of $\mathrm{CH}_{4}$ per minute. 


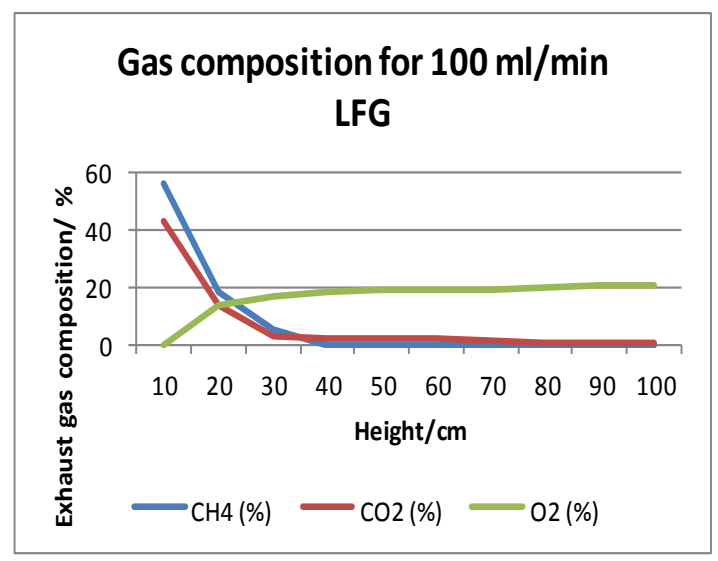

Figure 2a Black soil with $100 \mathrm{ml} / \mathrm{min}$ of LFG

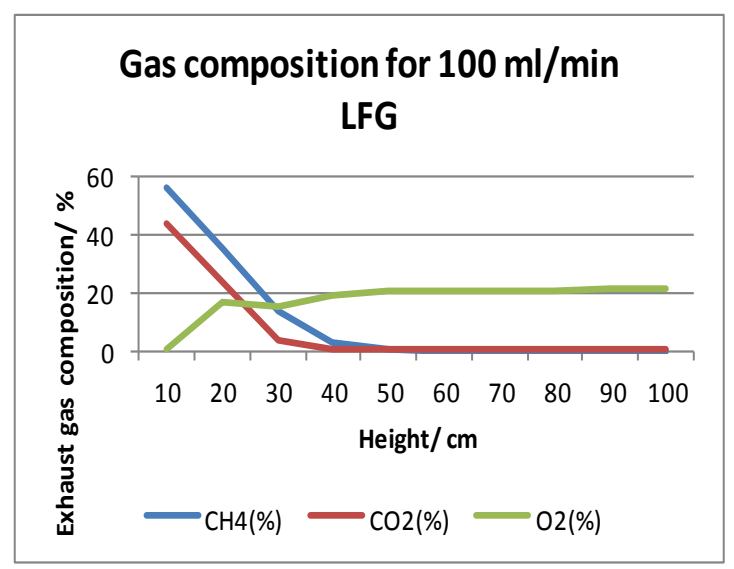

Figure 2b Black soil with $200 \mathrm{ml} / \mathrm{min}$ of LFG

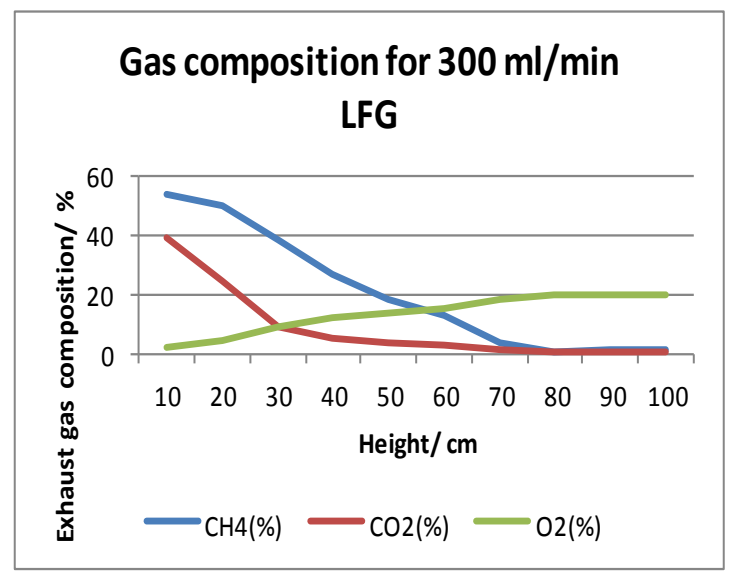

Figure 2c Black soil with $300 \mathrm{ml} / \mathrm{min}$ of LFG

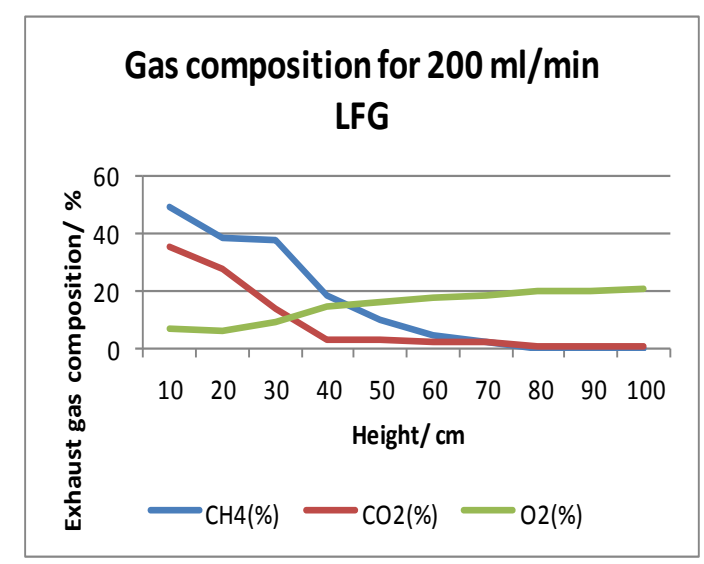

Figure 3a Compost with $100 \mathrm{ml} / \mathrm{min}$ of LFG

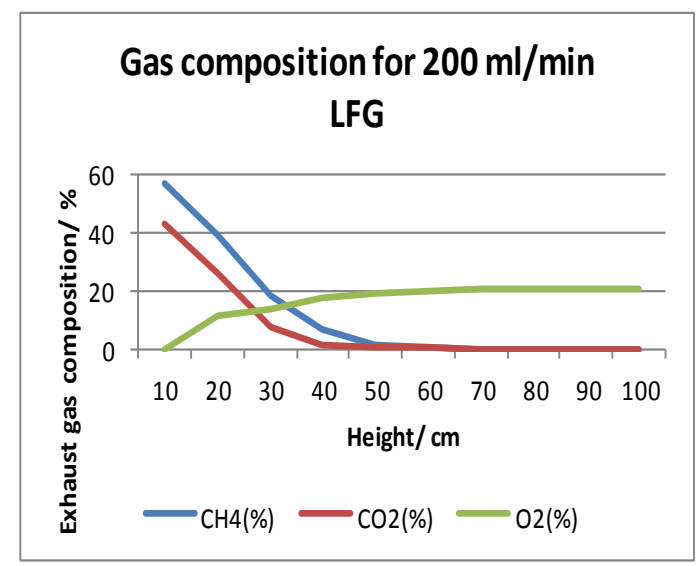

Figure 3b Compost with $200 \mathrm{ml} / \mathrm{min}$ of LFG

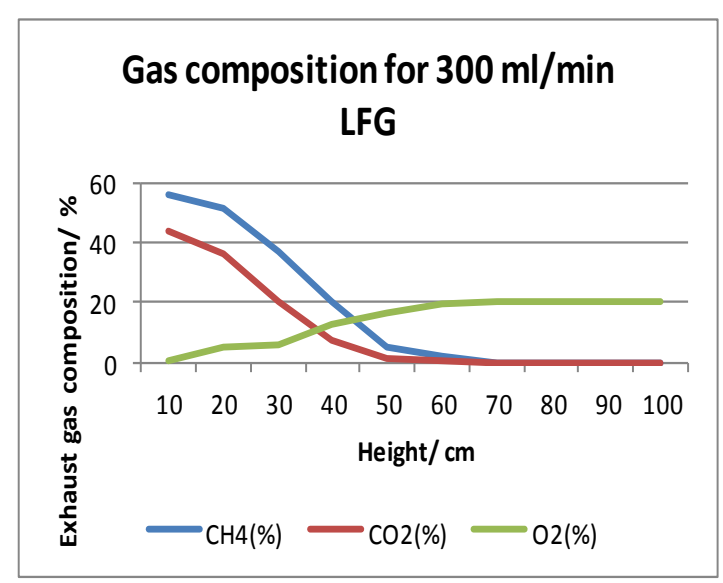

Figure 3c Compost with $300 \mathrm{ml} / \mathrm{min}$ of LFG 
Table 2 shows the summary for $\mathrm{CH}_{4}$ oxidation capacity of compost to be at the height of $90 \mathrm{~cm}$ for the maximum flow rate of $300 \mathrm{ml} / \mathrm{min}$. The height for full $\mathrm{CH}_{4}$ oxidation for black soil is lower than compost for $100 \mathrm{ml} / \mathrm{min}$ flow of LFG $33 \%$ better than compost. However, at $200 \mathrm{ml} / \mathrm{min}$, compost out performs black soil by $22 \%$, and at $300 \mathrm{ml} / \mathrm{min}$ the maximum height $(100 \mathrm{~cm})$ of black soil is insufficient for oxidation. Overall, column experiments using compost exhibited better $\mathrm{CH}_{4}$ oxidation compared to black soil.

Table 2. BioCover oxidation capacity

\begin{tabular}{|l|c|c|}
\hline \multirow{2}{*}{$\begin{array}{l}\text { Flow rate } \\
(\mathrm{ml} / \mathrm{min})\end{array}$} & \multicolumn{2}{|c|}{ Height of full oxidation $(\mathrm{cm})$} \\
\cline { 2 - 3 } & Compost & Black soil \\
\hline
\end{tabular}

\begin{tabular}{|c|c|c|}
\hline $\mathbf{1 0 0}$ & 60 & 40 \\
\hline $\mathbf{2 0 0}$ & 70 & 90 \\
\hline $\mathbf{3 0 0}$ & 90 & $>100$ \\
\hline
\end{tabular}

The above results show that $\mathrm{CH}_{4}$ oxidation capacity of black soil is lower than that of compost. The reason behind the difference in oxidation capacity can be explained from the physiochemical properties of both cover materials. This could be due to the acidic condition of the soil which inhibits the methanotrophic activity in black soil. According to Pawloska [7], it is also possible that the drop in $\mathrm{CH}_{4}$ concentration could be the result from the activity of yeasts that easily adapts to an acidified medium.

Table 3. Physiochemical properties of compost and black soil used for $\mathrm{CH}_{4}$ oxidation

\begin{tabular}{|l|l|l|}
\hline Test parameter & Compost & Black soil \\
\hline Moisture content & $63.17 \pm 0.14 \% \mathrm{v} / \mathrm{v}$ & $43.12 \pm 0.14 \% \mathrm{v} / \mathrm{v}$ \\
\hline pH & $6.33 \pm 0.12$ & $6.02 \pm 0.12$ \\
\hline Organic matter & $63.6 \%$ & $40.0 \%$ \\
\hline Total carbon $(\%)$ & $20.3 \%$ & $16.2 \%$ \\
\hline Total nitrogen & $1.20 \%$ & $1.10 \%$ \\
\hline Carbon: Nitrogen ratio & 17.0 & 14.7 \\
\hline
\end{tabular}

Table 3 shows the physiochemical properties of the Biocover materials namely compost and black soil. The compost moisture content is significantly higher than that of black soil. The ability of Biocover material to retain water is important to sustain microbial population responsible for $\mathrm{CH}_{4}$ oxidation. According to Pawloska [7], $\mathrm{CH}_{4}$ oxidation becomes limited if there is lack of water due to the physiological stress to methanotrophs present in cover material. Hilger and Humer [8] indicated that compost offers good water holding capacity, thus optimizing $\mathrm{CH}_{4}$ oxidation.

As indicated in Table 3, the organic matter present in cover materials produces a significant impact on oxidation performances [8]. Literature reports provide extensive proof of the effects of organic matter content on physical parameters in soil [9]. The nutrient status in a substrate is substantially affected by the organic matter content. Compost, with higher organic matter and carbon \& nitrogen content performs better than black soil in $\mathrm{CH}_{4}$ oxidation. Methanotrophic bacteria have a relatively high nitrogen demand [10].

Data from field studies have also shown the relative decrease in ammonia with increase in time and column height. Therefore for field applications, it is important for cover materials to provide sufficient nitrogen supply to support $\mathrm{CH}_{4}$ oxidation. However, landfills with a high ratio of $\mathrm{CH}_{4}$ to nitrogen may cause limitation of inorganic nitrogen for the bacterial colony present in the cover materials [11]. Field and laboratory studies also show $\mathrm{CH}_{4}$ oxidation rate in landfill cover soils change with ambient conditions [12], [13], and [14]. However, the 
sensitivity of $\mathrm{CH}_{4}$ oxidation to environmental factors in landfill cover soils, especially in nitrogen stress, including ammonia volatilization and nitrification is still not well known.

Anaerobic oxidation of $\mathrm{CH}_{4}$ occurs in marine, sediment and submerged soils [15], [16], [17], but most $\mathrm{CH}_{4}$ is consumed in landfill covers under aerobic condition. The $\mathrm{CH}_{4}$ oxidation rate was low atthe base of the columns. This was probably due to the existence of oxygen in the soil porosity, where aerobic $\mathrm{CH}_{4}$ oxidation occurred. As oxygen concentration increased, cover $\mathrm{CH}_{4}$ oxidation reduction presented an increasing trend.

Another important parameter provided by organic matter in a material capable of enhancing $\mathrm{CH}_{4}$ oxidation is the internal specific surface area which is the surface area to volume or mass ratio. In biofilter operation, specific surface area is regarded as the determining factor underlying mass exchange and biological reaction [18], [19]. Although it is an acknowledged fact that specific surface area increases with the higher organic matter content in a substrate, specific surface area parameter has been rather neglected to date [20].

\section{CONCLUSION}

The results from this study have shown that compost has a better $\mathrm{CH}_{4}$ oxidation capacity of than black soil under field conditions. At $100 \mathrm{~cm}$ of cover height and flow rate of $300 \mathrm{ml}$ per minute, black soil has an oxidation capacity of $112.2 \mathrm{ml} \mathrm{CH}_{4}$ per minute. For compost, the oxidation capacity is $169.8 \mathrm{ml} \mathrm{CH}_{4}$ per minute. However, further studies on other parameters in this experiment are still ongoing.

\section{ACKNOWLEDGEMENT}

The authors thank all individuals directly or indirectly involved in this project for their academic and technical support. We thank the Ministry of Science, Technology and Innovation (MOSTI) Science Fund (12-02-03-2077) and University of Malaya PPP (PS298/2010B) for providing the funding necessary for realizing the project. We also thank Jeram Sanitary Landfill for their contributions.

\section{REFERENCES}

1. Agamuthu, P. and Fauziah S.H. 2011. Challenges and issues in moving towards sustainable landfilling in a transitory country- Malaysia. Waste Management and Research. 29(1):13-19.

2. Agamuthu, P., Khidzir, K. and Fauziah S.H. (2009): Drivers of sustainable waste management in Asia. Waste Management and Research.27:625-633.

3. Malaysian national solid waste management department (NSWMD) 2011. http://www.kpkt.gov.my/jpspn/main.php?Co ntent=sections\&SectionID $=59 \&$ IID $=]$

4. Bogner, J., Abdelrafie Ahmed, M., Diaz, C., Faaij, A., Gao, Q., Hashimoto, S., Mareckova, K., Pipatti, R., Zhang, T., 2007. Waste management. In: Metz, B., Davidson, O.R., Bosch, P.R., Dave, R., Meyer, L.A., (Eds.), Climate Change 2007: Mitigation. Contribution of Working Group III to the Fourth Assessment Report of the Intergovernmental Panel on Climate Change, Cambridge University Press, Cambridge, United Kingdom and New York, NY, USA.

5. IPCC. 2007. Intergovernmental Panel on Climate Change, Climate Change 2007: Introduction. Cambridge University Press, Cambridge, UK.

6. Boeckx, P., Van Cleemput, O., Villaralvo, I., 1996. $\mathrm{CH}_{4}$ emission from a landfill and the $\mathrm{CH} 4$ oxidising capacity of its covering soil. Soil Biol. Biochem. 28, 1397-1405.

7. Pawloska, M. 2008. Reduction of $\mathrm{CH}_{4}$ emission from landfills by its microbial oxidation in filter bed.

8. Hilger, H., Humer, M., 2003. Biotic landfill cover treatments for mitigating $\mathrm{CH}_{4}$ emissions. Environ. Monit. Assess. 84, 7184.

9. Scheffer, F., Schachtschabel, P., 1984. Lehrbuch der Bodenkunde. Enke-Verlag, Stuttgart, Germany.

10. Scheutz, C., Kjeldsen, P., Bogner, J.E., De Visscher, A., Gebert, J., Hilger, H.A., Huber- Humer, M., Spokas, K., 2009a. Microbial $\mathrm{CH}_{4}$ oxidation processes and 
technologies for mitigation of landfill gas emissions. Waste Manage. Res. 27, 409455.

11. Bodelier, P.L.E., Laanbroek, H.J., 2004. Nitrogen as a regulatory factor of $\mathrm{CH}_{4}$ oxidation in soils and sediments. FEMS Microbiol. Ecol. 47, 265-277.

12. Chanton, J., Liptay, K., 2000. Seasonal variation in $\mathrm{CH}_{4}$ oxidation in landfill cover soils as determined by an in situ stable isotope technique. Global Biogeochem. Cycles 14, 51-60.

13. Scheutz, C., Kjeldsen, P., 2004. Environmental factors influencing attenuation of $\mathrm{CH} 4$ and hydrochlorofluorocarbons in landfill cover soils. J. Environ. Qual. 33, 72-79.

14. Albanna, M., Fernandes, L., Warith, M., 2007. CH4 oxidation in landfill cover soil; the combined effects of moisture content, nutrient addition, and cover thickness. $J$. Environ. Eng. Sci. 6, 191-200.

15. Hoehler, T.M., Alperin, M.J., Albert, D.B., Martens, C.S., 1994. Field and laboratory studies of $\mathrm{CH}_{4}$ oxidation in an anoxic marine sediments: evidence for methanogensulphate reducer consortium. Global Biogeochem. Cy. 8, 451-463.

16. Boetius, A., Ravenschlag, K., Schubert, C.J., Rickert, D., Widdel, F., Gieseke, A., Amann, R., Jørgensen, B.B., Witte, U., Pfannkuche, O., 2000. A marine microbial consortium apparently mediating anaerobic oxidation of $\mathrm{CH}_{4}$. Nature 407, 623-626.

17. Kallmeyer, J., Boetius, A., 2004. Effects of temperature and pressure on sulfate reduction and anaerobic oxidation of $\mathrm{CH}_{4}$ in hydrothermal sediments of guaymas basin. Appl. Environ. Microbiol. 70, 1231-1233.

18. Amanullah, M., Farooq, S., Viswanathan, S., 1999. Modeling and simulation of a biofilter. Ind. Eng. Chem. Res. 38, 2765812774.

19. Streese, J., Stegmann, R., 2003. Microbial oxidation of $\mathrm{CH}_{4}$ from old landfills in biofilters. Waste Manage. 23, 573-580.
20. Huber-Humer, M., Röder, S., Lechner, P., 2009. Approaches to assess BioCover performance on landfills. Waste Manage. 29, 2092-2104. 